\title{
Nutritional value of diets containing field bean (Vicia faba L.) seeds with high or low proanthocyanidin levels for pig $^{*}$
}

\author{
Marianna Flis' ${ }^{1}$, W. Sobotka' ${ }^{1}$, C. Purwin' ${ }^{1}$ and Z. Zduńczyk ${ }^{2}$ \\ 'Institute of Animal and Feed Management, University of Agriculture and Technology \\ Oczapowskiego 5, 10-718 Olsztyn, Poland \\ ${ }^{2}$ Institute of Animal Reproduction and Food Research, Division of Food Science, \\ Polish Academy of Sciences \\ Tuwima 10,10-718 Olsztyn, Poland
}

(Received 20 October 1998; accepted 19 March 1999)

\begin{abstract}
The nutritional value of pig diets containing about $30 \%$ ficld beans characterized by various levels of condensed tannins was studied. In a 54-day experiment on 24 Polish Large White $\mathrm{x}$ Duroc barrows (25-63 kg BW) four diets were fed: HT containing high-tannin ficld bcans (cv. Nadwiślański), LT with low-tannin field beans (cv. Caspar), DHT with hulled high-tannin field beans, and DHTF with hulled high-tannin field beans and added white flowering pea hull fibre. The proanthocyanidin content of the HT, LT, DHT and DHTF diets was $591,8,70$ and $70 \mathrm{mg} / \mathrm{kg}$, respectively. Nutrient and energy digestibility, nitrogen balance, daily weight gain, and feed utilization were determined.

The digestibility of $\mathrm{N}$-free extractives and energy was significantly higher $(\mathrm{P}<0.01)$, while that of crude protein was non significantly higher $(\mathrm{P}=0.07)$ in the LT and DHT diets than in the HT diet. Daily nitrogen retention and utilization did not differ significantly among groups. Daily body weight gains $(684-693 \mathrm{~g})$ and feed conversion $(3.02-3.07 \mathrm{~kg} / \mathrm{kg})$ also did not differ significantly among groups. Despite a slightly lower nutritional value as expressed by metabolizable energy and digestible protein, the HT diet that contained $0.1 \%$ phenols and $0.06 \%$ proanthocyanidins did not lower the growth rate of $25-63 \mathrm{~kg}$ pigs (which gained slightly under $700 \mathrm{~g}$ daily) in comparison with animals fed the LT and DHT diets.
\end{abstract}

KEY WORDS : field bean, proanthocyanidins, nutritional value, pigs

* A short version of this report was presented at the 3rd European Conference on Grain Legumes, 14-19 November 1998, Valladolid (Spain) 


\section{INTRODUCTION}

Polyphenols, especially condensed tannins (proanthocyanidins) are among the most important antinutrients in field beans. These compounds are found primarily in seed hulls. The amount of tannins can be decreased by selection for white-flowering low-tannin varieties, or by hulling seeds of high tannin varieties. In studies on pigs it was found that low-tannin varieties of field beans have higher crude protein and amino acid digestibilities (total and ileal) (Van der Poel et al., 1992; Grala et al., 1993; Jansman et al., 1993) and energy digestibility (Grosjean et al., 1995) than high-tannin varieties. The use of hulled seeds of high-tannin varieties also increases the digestibility of feed components, mainly energy (Pastuszewska et al., 1974; Bourdon and Perez 1992; Buraczewska et al., 1992; Flis et al., 1994).

In theory, the higher ileal and total crude protein and amino acid digestibility of field beans with a lowered tannin content, and their higher digestible and metabolizable energy levels should increase the nutritional value of these beans in the diets of pigs in comparison with high tannin seeds, however, the results of studies carried out to date are not unequivocal. In the experiments of Fekete et al. (1985) the nutritional value of diets containing $15 \%$ low-tannin field beans was similar to that of diets with high-tannin $(0.075 \%$ tannins $)$ varieties in the feeding of weaned pigs $(10-25 \mathrm{~kg})$. In contrast, in the studies of Grala et al. (1993) young pigs $(20-35 \mathrm{~kg})$ receiving ca. $30 \%$ low-tannin field beans in the diets had a significantly higher growth rate than those consuming high-tannin varieties. In these studies a reduction in growth rate and feed utilization was found when the tannin content of diets equaled $0.08 \%$. The results of the above studies show that lowering the tannin content in the diet to under $0.08 \%$ field bean tannins can increase the growth rate and improve feed utilization in very young pigs, but determining the precise admissible level of tannins is difficult, among others due to the various methods of estimating these compounds. It is also unknown if and to what degree lowering the content of field bean tannins in diets can affect the growth rate of fattening pigs.

The objective of this experiment was to determine the effects of lowering the total dietary contents of phenols and condensed tannins from field beans by using a low-tannin field bean variety or hulled seeds of high-tannin varieties on the digestibility of dietary components, nitrogen balance, body weight gain and feed utilization in the first phase of fattening.

\section{MATERIAL AND METHODS}

\section{Animals and diets}

Four groups each of 6 Polish Large White $x$ Duroc barrows with a starting weight of $25 \mathrm{~kg}$ were fed one of four diets: HT, with high-tannin field beans; LT, 
with low-tannin field beans; DHT, with hulled high-tannin field beans and added white-flowering pea hull fibre (Table 1). The spring varieties of field beans used were: the Polish coloured-flowered variety Nadwiślański (HT) and Dutch whiteflowering Caspar (LT) imported from Germany. The HT field beans were hulled mechanically and the hulls were blow-separated. The yield of hulled seeds was $80 \%$, but the hulling was not complete since $2.3 \%$ of the hull remained in the cotyledons. The content of field beans in the diets was 27.8 (diets DHT and DHTF), 30 (HT) and $33.2 \%$ (diet LT) and supplied about $45 \%$ of total crude protein in the diet. The remainder of the dietary crude protein was from soyabcan oilmeal and cereals.

The diets were balanced according to the Nutrient Requirements of Pigs (1993). They contained about $17 \%$ crude protein and, after supplementation with crystalline lysine and methionine, contained $0.9 \%$ lysine and $0.27 \%$ methionine (Table 1 ).

The experiment lasted 54 days. The pigs were maintained in individual metabolic cages and were fed twice daily on mash diets, mixed with water (feed:water 1:1); feeding level ranged from 1.4 to $2.4 \mathrm{~kg}$. On day $45-50$ of the experiment (at 56 $\mathrm{kg} \mathrm{BW}$ ), nitrogen balance and nutrient and energy digestibility were determined by the balance method. Faeces and urine collections were carried out for 5 days. Two average samples of $10 \%$ were taken from pooled one-day collections. One sample was preserved with sulphuric acid, the other dried. Nitrogen was determined in the sulphuric acid-preserved sample, the other was used to estimate the remaining components and energy. Urine collected in containers was preserved with sulphuric acid and $3 \%$ of the daily amount was used for nitrogen determination.

\section{Chemical analysis}

The basic nutrient components of feeds and in faeces, as well as urinary $\mathrm{N}$ were determined by conventional methods. Total energy in feed mixtures and in dried faeces was determined using an adiabatic bomb calorimeter. NDF and ADF in feeds were determined according to Van Soest and Wine (1967) using a Fibertec apparatus. The starch content was determined polarimetrically after eluting soluble sugars with $70 \%$ ethanol (Soral-Śmietana, 1993).

Total phenols and proanthocyanidins in diets were computed from their content in the ingredient. Phenols were determined using a colour reaction with the FolinCiocalteau reagent (Naczk and Shahidi, 1989), proanthocyanidins (condensed tannins) by a dye reaction of cyanidine in butanol-HCL (Oszmiański et al., 1988). The amino acid composition of feed protein was determined using a Czech AAAT 339 $\mathrm{M}$ amino acid analyzer. The metabolizable energy content in diets was calculated using the Hoffman and Schieman equation on the basis of the chemical composition and digestibility coefficients determined experimentally, adjusting for sugar and bacterial fermentation of structural polysaccharides according to Müller and Kirchgessner (Nutrient Requirements of Pigs, 1993). 
Composition and nutritional value of diets for growing pigs (26-63 kg BW)

\begin{tabular}{|c|c|c|c|c|}
\hline \multirow[t]{2}{*}{ Indices } & \multicolumn{4}{|c|}{ Diet $^{\prime}$} \\
\hline & HT & LT & DHT & DHTF \\
\hline \multicolumn{5}{|l|}{ Ingredients, $\mathrm{g} / \mathrm{kg}$} \\
\hline barley & 413.0 & 371.1 & 440.0 & 411.9 \\
\hline wheat & 200.0 & 200.0 & 200.0 & 200.0 \\
\hline soyabean meal & 55.0 & 65.0 & 50.0 & 50.0 \\
\hline field bean cv. Nadwiślański (HT) & 300.0 & - & - & - \\
\hline field bean cv. Caspar (LT) & - & 332.0 & - & - \\
\hline dehulled cv. Nadwiślański (DHT) & - & - & 278.0 & 278.0 \\
\hline pea hulls & - & - & - & 28.0 \\
\hline minerals $^{2}$ & 24.0 & 24.0 & 24.0 & 24.0 \\
\hline mineral-vitamin premix & 7.0 & 7.0 & 7.0 & 7.0 \\
\hline L-lysine HCL (78\%) & 0.3 & 0.2 & 0.3 & 0.4 \\
\hline DL-methionine (99\%) & 0.7 & 0.7 & 0.7 & 0.7 \\
\hline \multicolumn{5}{|l|}{ Chemical analysis, $\%$ air dry basis } \\
\hline dry matter & 87.46 & 87.34 & 87.28 & 87.36 \\
\hline crude ash & 4.34 & 4.37 & 4.16 & 4.50 \\
\hline crude protein & 16.89 & 16.75 & 17.12 & 17.03 \\
\hline crude fibre & 4.87 & 4.89 & 3.45 & 4.76 \\
\hline ADF & 6.25 & 6.24 & 4.62 & 6.10 \\
\hline phenols, $\mathrm{mg} / \mathrm{kg}$ & 1035 & 510 & 622 & 634 \\
\hline proanthocyanidins, $\mathrm{mg} / \mathrm{kg}$ & 591 & 8 & 70 & 70 \\
\hline \multicolumn{5}{|l|}{ Nutritional value, $\mathrm{g} / \mathrm{kg}$} \\
\hline lysine & 9.02 & 9.05 & 8.97 & 9.00 \\
\hline methionine & 2.73 & 2.72 & 2.75 & 2.70 \\
\hline threonine & 5.94 & 5.96 & 5.95 & 5.90 \\
\hline tryptophan & 1.75 & 1.83 & 1.75 & 1.70 \\
\hline $\mathrm{Ca}$ & 7.48 & 7.54 & 7.44 & 7.50 \\
\hline P-total & 5.60 & 5.64 & 5.55 & 5.50 \\
\hline digestible $\mathrm{CP}, \mathrm{g} / \mathrm{kg}^{3}$ & 131 & 134 & 136 & 135 \\
\hline metabolizable energy, $\mathrm{MJ} / \mathrm{kg}^{3}$ & 12.43 & 12.77 & 12.91 & 12.60 \\
\hline crude protein from field bean, $\%$ & 45 & 45 & 45 & 45 \\
\hline
\end{tabular}

${ }^{1} \mathrm{HT}=$ high tannin diet, $\mathrm{LT}=$ low tannin diet, DHT $=$ dehulled high tannin diet, DHTF $=$ dehulled high tannin diet + fibre from pea seed hulls

2 limestone $(1.3 \%)+$ bicalcium phosphate $(0.8 \%)+$ salt $(0.3 \%)$

${ }^{3}$ value calculated according to chemical composition of diet and digestibility coefficients of nutrients of diets 


\section{Statistical analysis}

The results were subjected to one-way variance analysis and the Duncan multiple range test. The correlations between phenols and proanthocyanidins intake with crude protein and gross energy digestibilities of the diets were computed.

\section{RESULTS AND DISCUSSION}

Hulling high-tannin field bean seeds led to an increased crude protein content ( 32.00 vs. $29.47 \%$ ) and a decrease in cell wall polysaccharide contents; total fibre and ADL were affected more ( 2.77 vs $8.21 \%$ and 0.50 vs $1.31 \%$, respectively), while NDF was less affected (15.22 vs $17.81 \%$; Table 2). In other studies (Buraczewska et al., 1992; Flis et al., 1994) similar changes in the composition of field beans after hulling were found. The pea hulls used in the DHTF diet to bring the ADF level up to that in group HT were well cleaned, as indicated by the very low content of crude protein and starch and the high content of crude fibre and ADF $(65.7 \%)$. Nearly identical contents of CF, ADF and NDF in pea hulls were found in a study by Leterme et al. (1996).

The content of phenolic compounds in HT field beans in our study was lower than the content of tannins found in the coloured-flowered varieties of field beans, while the content of phenols in LT field beans (Caspar) was higher than of tannins in white-flowering varieties of field beans in the works of Jansman et al. (1993) and Grosjean et al. (1995). The proanthocyanidin contents found in our experiment (2.28 and $0.03 \mathrm{~g} / \mathrm{kg}$ DM in HT and LT varieties) was closer to the level of tannins in analogous varieties of field beans (Grala et al., 1993). The somewhat lower level of proanthocyanidins in the seeds of both varieties could have resulted from their partial oxidation during the relatively long (about 1 year) storage of the seeds after harvesting. The hulled high tannin seeds contained $35 \%$ less phenols and about 8 times less proanthocyanidins than whole seeds, however, the content of these compounds in hulled seeds was higher than in the low tannin variety of field bean.

The protein of hulled field beans contained less methionine than the protein from whole beans $(0.70$ vs $0.89 \mathrm{~g} / 16 \mathrm{gN})$. The content of other essential amino acids was similar in HT, DHT and LT field beans (Table 2). The metabolizable energy content in hulled beans, estimated from chemical composition, was about $5 \%$ higher than in whole seeds ( 15.78 vs $15.03 \mathrm{MJ} / \mathrm{kgDM})$. The estimated increase in metabolizable energy due to hulling of field beans was lower than the 9-11\% rise in digestible energy found in earlier studies on animals (Pastuszewska et al., 1974; Flis et al., 1994)

The digestibility of dietary components of the LT diet containing the low-tannin field beans and the DHT diet containing hulled high tannin field beans was similar 
TABLE 2

Chemical composition of high-tanin (HT), low-tannin (LT), dehulled high tannin (DHT) field bean seeds and pea hulls, \% DM

\begin{tabular}{lrrrr}
\hline \multirow{2}{*}{ Item } & \multicolumn{3}{c}{ Field bean } & Pea hulls \\
\cline { 2 - 4 } & \multicolumn{1}{c}{ HT } & \multicolumn{1}{c}{ LT } & \multicolumn{1}{c}{ DHT } \\
\hline Dry matter & 86.23 & 86.81 & 86.35 & 88.08 \\
Ash & 3.36 & 4.07 & 3.58 & 2.97 \\
Crude protein & 29.39 & 26.36 & 31.99 & 4.50 \\
Ether extract & 1.55 & 1.37 & 1.34 & 0.56 \\
Crude fibre & 8.21 & 7.51 & 2.77 & 57.70 \\
NDF & 17.81 & 18.00 & 15.22 & 70.07 \\
ADF & 11.25 & 10.55 & 4.84 & 65.69 \\
ADL & 1.31 & 1.29 & 0.50 & 0.67 \\
NDF-ADF (hemicelluloses) & 6.56 & 7.45 & 10.38 & 4.38 \\
ADF-ADL (cellulose) & 9.94 & 9.26 & 4.34 & 65.02 \\
Starch & 43.98 & 44.60 & 45.80 & 10.40 \\
Phenols', g/kg DM & 4.00 & 1.77 & 2.59 & 0.48 \\
ProACs ${ }^{2}$, g/kg DM & 2.28 & 0.03 & 0.29 & Trace \\
AA, g/16 gN & & & & \\
$\quad$ lysine & & & & \\
threonine & 6.64 & 6.69 & 6.65 & 6.86 \\
methionine & 3.53 & 3.57 & 3.51 & 3.96 \\
cystine & 0.89 & 0.93 & 0.70 & 1.35 \\
Gross energy, MJ/kg DM & 1.26 & 1.31 & 1.32 & 1.62 \\
ME, MJ/kg DM ${ }^{3}$ & 19.33 & 18.96 & 19.28 & 18.84 \\
\hline
\end{tabular}

' as sinapic acid

${ }^{2}$ proanthocyanidins-as cyanidin chloride

${ }^{3}$ calculated from chemical composition according to Noblet and Perez (1993; equation no. 37)

(Table 3). In comparison with the HT diet, nitrogen-free extractives (NFE) and gross energy (GE) of diets LT and DHT were significantly better digested $(\mathrm{P}<0.01)$, but the digestibility of crude protein $(\mathrm{CP})$ and crude fibre $(\mathrm{CF})$ although slightly higher, did not differ significantly. Comparison of the digestibility of diets HT, LT and DHTF, that did not differ in ADF contents, but differed in the contents of phenols and proanthocyanidins, shows that ADF had a negative effect on the digestibility of GE, NFE and, to a lesser degree, on the digestibility of CP and CF. The correlation between the consumption of phenols and proanthocyanidins with crude protein and energy digestibility was significantly negative (Table 4 ). The difference in the digestibility of components in diets DHT and DHTF, containing equal amounts of proanthocyanidins but different amounts of ADF, and the differences in the digestibility between diet HT and DHT, differing both in proanthocyanidins and ADF contents, showed a greater effect of proanthocyanidins than ADF on digestibility in pigs. This could have been caused by small differences in the ADF content 
TABLE 3

Digestibility coeflicients, $\mathrm{N}$ balance and growth performance of growing pigs fed HT, LT, DHT and DHTF dicts

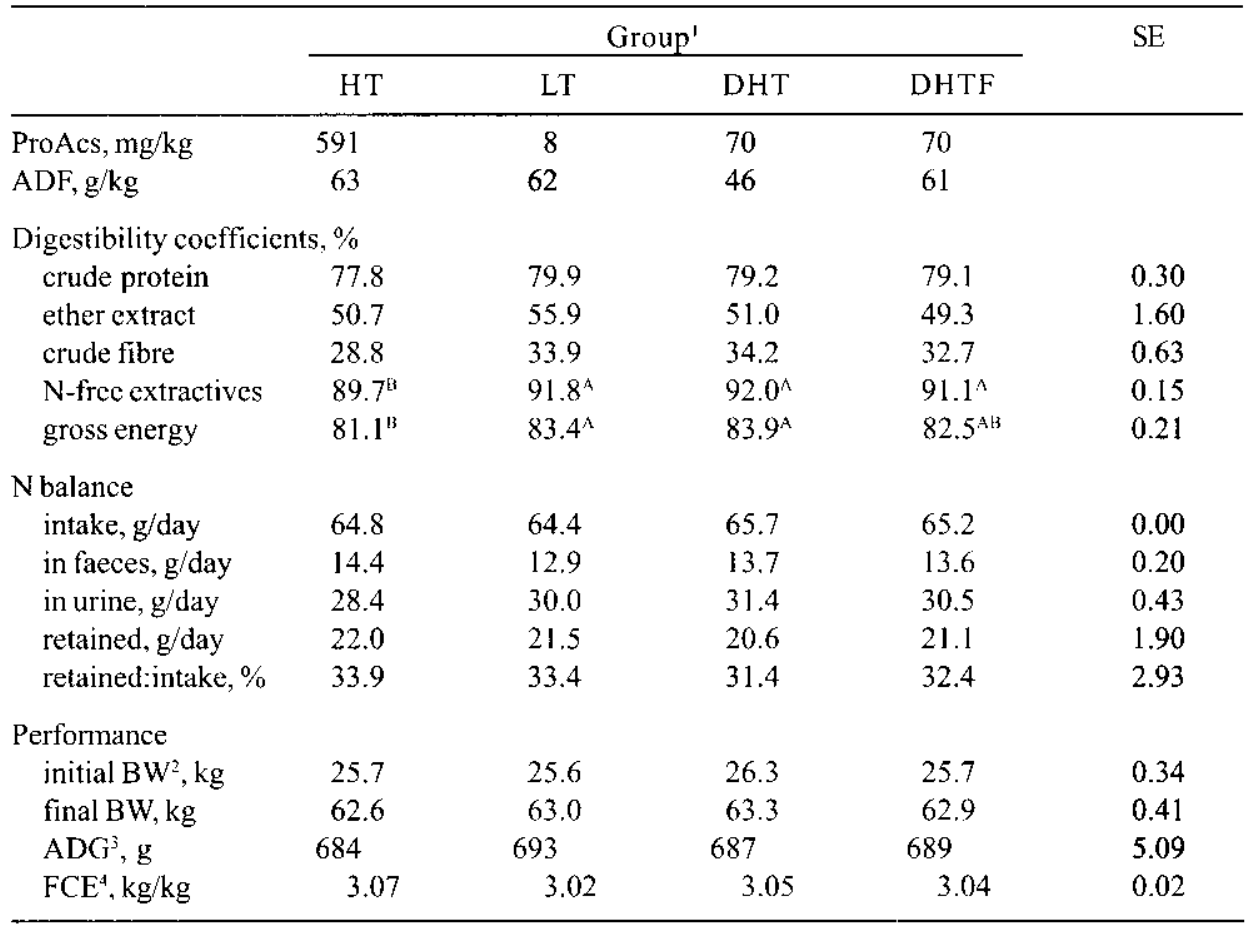

' see Table 1; ' body weight; ${ }^{3}$ average daily gain; ${ }^{4}$ feed conversion efficiency

$\mathrm{AB}-\mathrm{P} \leq 0.01$

TABLE 4

Correlations and regression between dietary parameters and digestibility of crude protein and gross energy $(y=a+b x)$

\begin{tabular}{llccc}
\hline \multicolumn{1}{c}{$\mathrm{X}$} & \multicolumn{1}{c}{$\mathrm{Y}$} & $\begin{array}{c}\text { Correlation } \\
\text { coefficient }\end{array}$ & $\begin{array}{c}\text { Intercept } \\
\mathrm{a}\end{array}$ & $\begin{array}{c}\text { Slope } \\
\mathrm{b}\end{array}$ \\
\hline $\begin{array}{l}\text { Phenols } \\
\text { intake }\end{array}$ & $\begin{array}{l}\text { Protein } \\
\text { digestibility } \\
\mathrm{n}=18\end{array}$ & $-0.495^{*}$ & 81.73 & -0.0016 \\
$\begin{array}{l}\text { Phenols } \\
\text { intake }\end{array}$ & $\begin{array}{l}\text { Energy } \\
\text { digestibility }\end{array}$ & $-0.661^{* *}$ & 85.58 & -0.0019 \\
$\begin{array}{l}\text { ProACs } \\
\text { intake }\end{array}$ & $\begin{array}{l}\text { Protein } \\
\text { digestibility } \\
\mathrm{n}=18\end{array}$ & $-0.480^{*}$ & 79.66 & -0.0013 \\
$\begin{array}{l}\text { ProACs } \\
\text { intake }\end{array}$ & $\begin{array}{l}\text { Energy } \\
\text { digestibility }\end{array}$ & $-0.641^{* *}$ & 83.11 & -0.0016 \\
\hline
\end{tabular}

* significant at $\mathrm{P}<0.05 ;{ }^{* *}$ significant at $\mathrm{P}<0.01$ 
in diets when whole field beans were replaced by hulled beans $(6.30 \mathrm{vs} 4.60 \%$, respectively for diets HT and DHT).

At an approximately $30 \%$ content of field beans in the diets of $56 \mathrm{~kg}$ pigs, the replacement of high tannin seeds with low-tannin ones led to increased crude protein digestibility by 2.1 , and of energy by 2.3 percentage points. Similar results were obtained in studies on $15-30 \mathrm{~kg}$ pigs by Jansman et al. (1993). In their studies, diets with $30 \%$ coloured-flowered field beans had 1.7-3.9 percentage point lower crude protein digestibility and 1.2-2.7 percentage point lower organic matter digestibility than a diet with white-flowering field beans, depending on the tannin content. Also in the studies of Grala et al. (1993) the digestibility of components of diets containing about $30 \%$ high tannin varieties of field beans was significantly lower in young pigs than of a diet with the white-flowering variety.

A significant rise in the digestibility of NFE and GE and an insignificant increase in the digestibility of CP in the DHT diet, with hulled seeds, in our experiment is in agreement with the results of other authors. In the study by Buraczewska et al. (1992) the ileal digestibility of a semi-synthetic diet containing about $45 \%$ hulled field beans was non significantly higher, and the digestibility of organic matter was significantly higher than of the diet with whole field beans. Also Bourdon and Perez (1992), on the basis of results obtained in France, stated that hulling field beans increases the digestibility of crude protein and energy, but affects energy digestibility more.

Pigs in group DHT fed hulled field beans in comparison with those in group HT fed whole beans excreted slightly less nitrogen in faeces, and insignificantly more nitrogen in urine ( $31.4 \mathrm{vs} 28.4 \mathrm{~g} /$ day; Table 3 ). In earlier studies, and using higher amounts of field beans in diets ( 51 and 46\%), Pastuszewska et al. (1974) found that pigs recciving hulled field beans excrete significantly less nitrogen in faeces and more in urine than pigs fed whole field beans. In the present study daily nitrogen retention and utilization of absorbed nitrogen did not differ significantly among groups, and only in the group receiving hulled field beans daily nitrogen retention and the ratio of the nitrogen retained to nitrogen intake were somewhat lower than in the remaining groups.

In the period of growth from 25 to $63 \mathrm{~kg}$ body weight, average daily gain (ADG) was 684 to $693 \mathrm{~g}$ and did not differ significantly among groups. Feed utilization (FCR) equaled 3.02 to $3.07 \mathrm{~kg}$ per $\mathrm{kg}$ body weight gain and was not significantly different. Fekete et al. (1985) also did not find significant differences in ADG and FCR in $10-25 \mathrm{~kg}$ pigs fed diets containing $15 \% \mathrm{HT}$ or LT field beans. However, Grala et al. (1993) using diets containing about $30 \%$ field beans found that the lower level of condensed tannins in field beans had a positive effect on the growth rate of young (20-35 kg) pigs. In the studies of the cited authors, a significant decrease in daily gains was found even at a small, $0.08 \%$, content of tannins in diets. In our studies, the content of phenols and proanthocyanidins in the HT diet 
was 0.1 and $0.06 \%$, respectively. It results from this that such a level of these ANFs in the diet of 25-63 kg pigs that gain under $700 \mathrm{~g}$ daily does not affect their growth rate. It may also suggest that the negative effects of the tannins would have been visible if the pigs had a higher growth rate, or if a lower level of crude protein and metabolizable energy had been used in the diet.

\section{CONCLUSIONS}

It could be concluded that the LT diet with the low-tannin field beans and the DHT diet with hulled high-tannin field beans containing low levels of proanthocyanidins had a significantly higher energy digestibility and slightly higher $(\mathrm{P}=0.07)$ crude protein digestibility than the HT diet with high-tannin field beans containing the highest level of proanthocyanidins. The HT diet with $0.1 \%$ phenolic compounds and $0.06 \%$ proanthocyanidins, despite a somewhat lower nutritional value measured as the metabolizable energy and crude protein contents, did not lower the growth rate of $25-63 \mathrm{~kg}$ pigs that gained somewhat under $700 \mathrm{~g}$ daily, in comparison with those fed the LT or DHT diets.

\section{REFERENCE}

Bourdon D., Perez J.M., 1992. Energy and protein values of faba beans (Vicia faba minor L.) for pigs : synthesis of French results. Proceedings of 1 st European Conference on Grain Legumes, Angers (France), pp. 521-522

Buraczewska L., Gdala J., Grala W., 1992. Ileal digestibility of nutrients in pigs fed diets with raw or processed field bean. Proceedings of 1st European Conference on Grain Legumes, Angers (France), pp. $517-518$

Fekete J., Willequet F., Gatel F., Quemere P., Grosjean F., 1985. Utilisation de féverole par le porcelet sevré. Comparaison de niveaux et variétés. Journées Rech. Porcine, 17, 397-406

Flis M., Lewicki C., Mieszkalski L., Bednarska A., 1994. Chemical composition, digestibility and nutritive value of dehulled or fractionated faba bean seeds used for feeding pigs (in Polish). Acta Acad. Agric. Tech. Olst., Zoot. 42, 29-37

Grala W., Jansman A.J.M., Leeuwen P. van, Huisman J., Kempen G.J.M. van, Verstegen M. W. A., 1993. Nutritional value of faba beans (Vicia faba L.) fed to young pigs. J. Anim. Feed Sci. 2, 169-179

Grosjean F., Barrier-Guillot B., Jondreville C., Peyronnet C., 1995. Feeding value of different cultivars of faba beans (Vicia faba minor). Proceedings of 2 nd European Conference on Grain Legumes, Copenhagen (DK), pp. 308-309

Jansman A.J.M., Huisman J., van der Poel A.F.B., 1993. Ileal and faecal digestibility in piglets of field beans (Vicia faba L.) varying in tannin content. Anim. Feed Sci. Technol. 42, 83-96

Leterme P., Théwis A., van Leewen P., Monmart T., Huisman J., 1996. Chemical composition of pea fibre isolates and their effect on the endogenous amino acid flow at the ileum of the pig. J. Sci. Food Agric. 72, 127-134 
Naczk M., Shahidi F., 1989. Effect of methanol-ammonia-water treatment on the content of phenolics of canola. Food Chem. 31, 159-164

Noblet J., Perez J.M., 1993. Prediction of digestibility of nutrients and energy values of pig diets from chemical analysis. J. Anim. Sci. 71, 3389-3398

Nutrient Requirements of Pigs. Nutritive Value of Feeds (in Polish), 1993. The Kielanowski Institute of Animal Physiology and Nutrition (Editor). Jabłonna (Poland)

Oszmiański J., Ramos T., Bourzeix M., 1988. Fractionation of phenolic compounds in red wine. Amer. J. Enol, Vitic. 39-259-262

Pastuszewska B., Duée P.H., Henry Y., Bourdon D., Jung J., 1974. Utilisation de la féverole entiére et décortiquée par le porc en croissance : digestibilité et disponibilité des acides aminés. Ann. Zootech. 23, 537-554

Poel A.F.B van, Dellaert L.M.W., Norel A. van, Helsper J. P. F.G., 1992. The digestibility in piglets of faba bean (Vicia faba L.) as affected by breeding towards the absence of condensed tannins. Brit. J. Nutr. 68, 793-800

Soral-Śmietana M., 1993. Physico-chemical characteristics of faba bean starch. Acta Acad. Agric. Tech. Olst., Technol. Alim. 25, 137-150

Van Socst P.J., Wine R.H., 1967. Use of detergents in the analysis of fibrous feeds. IV. Determination of plant cell wall constituents. J. Assoc. Off. Anal. Chem. 50, 50-55

\section{STRESZCZENIE}

\section{Wartość odżywcza mieszanek $z$ udzialem nasion bobiku (Vicia faba L.) zawierających wysoki lub niski poziom proantocyjanidyn w żywieniu rosnących świń}

Oznaczono wartość odżywczą mieszanek 7 . udziałem około $30 \%$ nasion bobiku o zróżnicowanej zawartości skondensowanych tanin w 54-dniowym doświadezeniu przeprowadzonym na 24 wieprzkach mieszańcach rasy Wielkiej Białej Polskiej x Duroc (25-63 kg m.c.). Zastosowano cztery micszanki: HT - z udziałem nasion bobiku wysokotaninowego (Nadwiślański), LT - z nasionami bobiku niskotaninowego (Caspar), DHT - z odłuszczonymi nasionami bobiku wysokotaninowego i DHTF - z odłuszczonymi nasionami bobiku wysokotaninowego, ale z dodatkiem włókna $\mathrm{z}$ łuski białokwitnącego grochu. Zawartość proantocyjanidyn w mieszankach HT, LT, DHT i DHTF wynosiła odpowiednio 591, 8,70 i $70 \mathrm{mg} / \mathrm{kg}$. Oznaczono strawność skladników pokarmowych i energii mieszanck, bilans azotu oraz przyrosty dzienne i wykorzystanie paszy.

Stwierdzono istotnie większą $(\mathrm{P}<0,01)$ strawność związków bezazotowych wyciagowych i energii oraz nicistotnie większą ( $\mathrm{P}=0,07)$ strawność białka ogólnego mieszanek LT i DHT w porównaniu z mieszanką HT. Dobowa retencja azotu oraz wykorzystanie azotu pobranego, a także przyrosty dzienne (684-693g) i zużycie paszy $(3,02-3,07 \mathrm{~kg} / \mathrm{kg})$ nie różniło się istotnie między grupami. Mieszanka HT, zawierająca $0,1 \%$ fenoli i $0,06 \%$ proantocyjanidyn, mimo trochę mniejszej wartości pokarmowej, mierzonej zawartością energii metabolicznej i białka ogólncgo strawncgo, nie wpłync̨ła na zmniejszenie tempa wzrostu świń od 25 do $63 \mathrm{~kg}$ w porównaniu ze zwierzętami żywionymi mieszankami LT i DHT. 